\title{
The impact of different glacial boundary conditions on atmospheric dynamics and precipitation in the North Atlantic region
}

\author{
D. Hofer ${ }^{1,2}$, C. C. Raible ${ }^{1,2}$, A. Dehnert ${ }^{3}$, and J. Kuhlemann ${ }^{3}$ \\ ${ }^{1}$ Climate and Environmental Physics, Physics Institute, University of Bern, Bern, Switzerland \\ ${ }^{2}$ Oeschger Centre for Climate Change Research, University of Bern, Bern, Switzerland \\ ${ }^{3}$ Swiss Federal Nuclear Safety Inspectorate, Brugg, Switzerland
}

Correspondence to: D. Hofer (dhofer@ climate.unibe.ch)

Received: 7 December 2011 - Published in Clim. Past Discuss.: 4 January 2012

Revised: 3 May 2012 - Accepted: 3 May 2012 - Published: 24 May 2012

\begin{abstract}
Using a highly resolved atmospheric general circulation model, the impact of different glacial boundary conditions on precipitation and atmospheric dynamics in the North Atlantic region is investigated. Six 30-yr time slice experiments of the Last Glacial Maximum at 21 thousand years before the present $(\mathrm{kaBP})$ and of a less pronounced glacial state - the Middle Weichselian (65 ka BP) - are compared to analyse the sensitivity to changes in the ice sheet distribution, in the radiative forcing and in the prescribed time-varying sea surface temperature and sea ice, which are taken from a lower-resolved, but fully coupled atmosphere-ocean general circulation model.

The strongest differences are found for simulations with different heights of the Laurentide ice sheet. A high surface elevation of the Laurentide ice sheet leads to a southward displacement of the jet stream and the storm track in the North Atlantic region. These changes in the atmospheric dynamics generate a band of increased precipitation in the midlatitudes across the Atlantic to southern Europe in winter, while the precipitation pattern in summer is only marginally affected. The impact of the radiative forcing differences between the two glacial periods and of the prescribed timevarying sea surface temperatures and sea ice are of second order importance compared to the one of the Laurentide ice sheet. They affect the atmospheric dynamics and precipitation in a similar but less pronounced manner compared with the topographic changes.
\end{abstract}

\section{Introduction}

The climate in glacial periods is of great interest, as it represents a state that is fundamentally different compared to today. Especially the Last Glacial Maximum (LGM) around 21 thousand years before the present (ka BP) has been studied extensively (e.g. Mix et al., 2001). However, in many areas proxy data are sparse and even in some well-covered regions such as the Nordic Seas they show contradicting results (de Vernal et al., 2006). Consequently, the confidence intervals of reconstructed temperature and precipitation are large. The climate in earlier periods of the last glaciation is less understood as proxy data availability is further reduced. Sea level reconstructions indicate changes in the order of several tens of metres during the last glaciation (e.g. Siddall et al., 2008) suggesting strong variations of the total ice mass. For the LGM, the extent and height of the ice sheets are relatively well known (Peltier, 2004), but uncertainties strongly increase when going further back in time. Thus, for the earlier part of the last glacial period the knowledge not only of the climate, but also of the lower boundary conditions is limited due to the lack of proxy data. One way to overcome these limitations is the use of climate models which enables us to test different boundary conditions and to investigate their impact on the climate.

Such an approach has already been successfully applied to the LGM to evaluate models and to deepen our understanding of the climate system (Paleoclimate Model Intercomparison Project; PMIP; Joussaume and Taylor, 1995; Braconnot et al., 2007). In agreement with proxy reconstructions the largest cooling in LGM simulations is found over the ice 
sheets in the Northern Hemisphere while the tropical ocean shows only weak temperature changes (e.g. Braconnot et al., 2007; Otto-Bliesner et al., 2009). On a more regional scale, the results are less consistent, especially in the North Atlantic and the western Europe region, where proxy data (Peyron et al., 1998) indicate lower temperatures compared with simulations (Kageyama et al., 2006). The use of higher resolved models can reduce this difference, but does not completely solve the discrepancies (Jost et al., 2005; Ramstein et al., 2007; Kim et al., 2008). A more recent reconstruction, however, suggests that part of the difference is related to the reconstruction methods applied to the proxy data (Wu et al., 2007).

Regarding precipitation PMIP results suggest globally drier conditions - due to reduced evaporation as the temperature is lower - except for some mid-latitude areas (Shin et al., 2003; Braconnot et al., 2007). In the Northern Hemisphere the precipitation increase especially in winter is related to changes in the storm tracks which overcompensate the general drying (Laine et al., 2009). Previous results for PMIP indicated an eastward shift of the storm tracks in the Atlantic and Pacific with model-dependent characteristics linked to changes in the stationary waves (Kageyama et al., 1999). For four more recent PMIP simulations Laine et al. (2009) found a southeastward shift of the storm track in the North Pacific and a thinning in the western and a southeastward extension in the eastern part of the North Atlantic. These changes are related to a similar displacement of the jet stream partly forced by eddies as a consequence of the changed boundary conditions.

Precipitation changes are, however, not only a consequence of changed boundary conditions, but can also be a driver, e.g., precipitation is an important factor for the massbalance of glaciers and ice sheets. Kageyama and Valdes (2000) suggested a coupling between the Laurentide and the Fennoscandian ice sheets, as the height of the first influences the precipitation over the latter. Another study proposed that precipitation increases over the North Atlantic due to an altered height of the Laurentide ice sheet which reduces the ocean overturning circulation (Eisenman et al., 2009). Thus, a quantification of precipitation change under different glacial boundary conditions is important.

In this study, we extend the LGM case studies to an early part of the last glacial period, the Middle Weichselian (MW, $65 \mathrm{kaBP}$ which corresponds to a part of Marine Isotope Stage 4), by utilising a state-of-the-art atmospheric model forced with prescribed sea surface temperatures (SSTs) and sea ice fields derived from a lower-resolved, but fully coupled model. The MW is chosen because it represents a state which is closer to the beginning of the last glacial period than the LGM, but nevertheless includes a strong glaciation - as suggested by the low sea level (about $80 \mathrm{~m}$ below the present day level) compared to other periods in the Early/Middle Weichselian (Siddall et al., 2008). The aim is to examine the influence of different glacial boundary conditions on atmospheric dynamics and on the precipitation pattern in the North Atlantic region. This incorporates changes of the SST and sea ice, the radiative forcing and the topography of the ice sheets.

The outline of the study is as follows: the model, the experimental design and the boundary conditions are briefly explained in Sect. 2. In Sect. 3 the simulated temperature and precipitation patterns for present-day and LGM are evaluated against observations and a reconstruction. The analysis of the temperature and precipitation patterns for the different glacial simulations is presented in Sect. 4 and the changes of the atmospheric dynamics are examined in Sect. 5. The implication of the findings is discussed in Sect. 6.

\section{Model description and experiments}

\subsection{Model}

The study is based on simulations with version 3 and 4 of the Community Climate System Model (CCSM) developed at the National Center for Atmospheric Research (NCAR). Both model versions offer components for the atmosphere, the ocean, the land, the sea ice and a coupler which exchanges state information and fluxes.

We use the CCSM3 in its fully coupled mode - with a horizontal resolution of $2.8 \times 2.8^{\circ}$ for the atmosphere and land surface and nominal $1 \times 1^{\circ}$ for the ocean and sea ice grid. A description of the CCSM3 and its components is given in Collins et al. (2006). Note that this model version has been widely used for paleo-simulations (e.g. Otto-Bliesner et al., 2006a, for the LGM).

The CCSM4 is run with $0.9 \times 1.25^{\circ}$ resolution for the atmosphere and land surface with prescribed time-varying SSTs and sea ice cover. In this study, the CCSM4 consists of the Community Atmosphere Model version 4 (Neale et al., 2010) with a finite volume dynamical core and the Community Land Model version 4 (Oleson et al., 2010) excluding the integrated carbon-nitrogen model. The prescribed timevarying SSTs and sea ice are integrated via a data ocean model and the Community Ice Code version 4 (Hunke and Lipscomb, 2008) in its thermodynamic-only mode, respectively.

\subsection{Experiments}

To investigate the sensitivity of the glacial climate to changes in the boundary conditions a set of time-slice experiments is conducted considering four different time periods: presentday (1990 AD), preindustrial (1850 AD), LGM and MW. An overview of the simulations is presented in Table 1 and the values of the major external forcing factors are summarized in Table 2.

In principle, the simulations are generated as follows: First, a CCSM3 simulation under respective perpetual external forcing conditions is conducted until a sufficiently equilibrated state of the coupled atmosphere-ocean system 
Table 1. Overview of the simulations for the two model versions and the ice sheet topographies applied in CCSM4. The monthly mean SST and sea ice data of the five CCSM3 simulations are used as inputs for the corresponding CCSM4 experiments. The MW simulation for CCSM3 uses the same topography as the LGM one and its SST and sea ice fields serve as input in all the CCSM4's MW experiments which differ only in their ice sheet topographies (see also Fig. 1 and text). The values for the ice sheet heights indicate how much of Peltier's LGM-present-day topography changes are applied for the Fennoscandian, the Laurentide and all other (mainly Greenland and Antarctica) ice sheets.

\begin{tabular}{lrrrrr}
\hline Description & CCSM3 & $\begin{array}{r}\text { CCSM4 } \\
\text { Label }\end{array}$ & $\begin{array}{r}\text { Ice sheet heights } \\
\text { Fennoscandian }\end{array}$ & Laurentide & Others \\
\hline $\begin{array}{l}\text { Transient 1971-2000 AD } \\
\text { simulation }\end{array}$ & - & $\mathrm{PD}_{\mathrm{TR}}$ & $0 \%$ & $0 \%$ & $0 \%$ \\
1990 AD simulation & $\mathrm{a}$ & $\mathrm{PD}_{\mathrm{EQ}}$ & $0 \%$ & $0 \%$ & $0 \%$ \\
$1850 \mathrm{AD}$ simulation & $\mathrm{b}$ & $\mathrm{PI}$ & $0 \%$ & $0 \%$ & $0 \%$ \\
21 ka BP simulations & $\mathrm{c}$ & $\mathrm{LGM}_{\mathrm{MS}}$ & $100 \%$ & $100 \%$ & $100 \%$ \\
& $\mathrm{~d}$ & $\mathrm{LGM}_{\mathrm{EQ}}$ & $100 \%$ & $100 \%$ & $100 \%$ \\
65 ka BP simulations & $\mathrm{e}$ & $\mathrm{MW}_{\mathrm{LGM}}$ & $100 \%$ & $100 \%$ & $100 \%$ \\
& & $\mathrm{MW}_{\mathrm{LIN}}$ & $67 \%$ & $67 \%$ & $67 \%$ \\
& & $\mathrm{MW}$ & $33 \%$ & $76 \%$ & $76 \%$ \\
& & $\mathrm{MW}$ & $100 \%$ & $46 \%$ & $100 \%$ \\
\hline
\end{tabular}

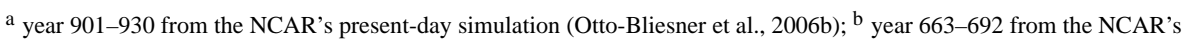
preindustrial simulation (Otto-Bliesner et al., 2006b); ${ }^{\mathrm{c}}$ started from year 250 of the NCAR's LGM simulation

(Otto-Bliesner et al., 2006a); ${ }^{\mathrm{d}}$ year 1766-1795 of the LGM simulation of Brandefelt and Otto-Bliesner (2009); ${ }^{\mathrm{e}}$ started from year 250 of the NCAR's LGM simulation (Otto-Bliesner et al., 2006a) and run into equilibrium for $340 \mathrm{yr}$.
}

Table 2. External forcing level for the four periods investigated in this study. The orbital parameters are calculated according to Berger (1978). Glacial levels of $\mathrm{CO}_{2}, \mathrm{CH}_{4}$ and $\mathrm{N}_{2} \mathrm{O}$ are estimated from ice cores according to Schilt et al. (2010) and B. Bereiter (personal communication, 2012) for MW and following the PMIP protocol for LGM (http://www-lsce.cea.fr/pmip2/). Note that the external forcing indicated in the table correspond to the values in the CCSM4 simulations and that they may slightly differ in the CCSM3 simulations, e.g., for 1850 AD the forcing in the CCSM3 simulation corresponds to $1870 \mathrm{AD}$.

\begin{tabular}{lrrrr}
\hline & $1990 \mathrm{AD}$ & $1850 \mathrm{AD}$ & $21 \mathrm{ka} \mathrm{BP}$ & $65 \mathrm{ka} \mathrm{BP}$ \\
\hline TSI $\left(\mathrm{Wm}^{-2}\right)$ & 1361.77 & 1360.89 & 1360.89 & 1360.89 \\
Eccentricity & 0.016708 & 0.016764 & 0.018994 & 0.020713 \\
Obliquity $\left(^{\circ}\right)$ & 23.441 & 23.459 & 22.949 & 22.564 \\
Angular precession $\left(^{\circ}\right)$ & 102.72 & 100.33 & 114.43 & 15.22 \\
$\mathrm{CO}_{2}(\mathrm{ppm})$ & 353.9 & 284.7 & 185 & 205 \\
$\mathrm{CH}_{4}(\mathrm{ppb})$ & 1693.6 & 791.6 & 350 & 460 \\
$\mathrm{~N}_{2} \mathrm{O}(\mathrm{ppb})$ & 310.1 & 275.7 & 200 & 210 \\
\hline
\end{tabular}

is reached so that the trends of the SSTs and sea ice cover are negligible. The monthly-mean SST and sea ice concentration fields are then interpolated from the irregular ocean grid in CCSM3 to a regular $0.9 \times 1.25^{\circ}$ grid and used as time-varying lower boundary conditions for the CCSM4 simulation. Second, the CCSM4 simulation is conducted for 33 model years and the analysis is based on the last 30 model years of the simulation.

This two-model approach is selected to profit from the results of earlier CCSM3 simulations, which saves computational costs, while still using an up-to-date highly resolved atmospheric model in the second step. Pre-existing equilibrated CCSM3 simulations are available for all periods (Otto-Bliesner et al., 2006a,b; Brandefelt and Otto-Bliesner, 2009) except for the MW. The MW simulation based on CCSM3 is initialised from the LGM state (Otto-Bliesner et al., 2006a). This choice obliges some simplifications in the set-up of the MW simulation: the bathymetry and topography are similar to LGM corresponding to no sea level change between LGM and MW, which could lead to biases in the ocean surface. However, due to the low resolution the topography in the CCSM3 simulations is rather crude anyway and the impact of differences in the prescribed ocean surface for the CCSM4 simulation is one of the investigated factors in this study. The MW simulation is conducted for $340 \mathrm{yr}$ until the ocean surface is sufficiently equilibrated (global mean SST trend less than $0.1^{\circ} \mathrm{C}$ per century).

Using CCSM4 the following time-slice experiments are conducted (Table 1): 
- A present-day simulation with perpetual 1990 AD conditions (hereafter $\mathrm{PD}_{\mathrm{EQ}}$ ), which is used to evaluate the model's present-day climate.

- A preindustrial simulation with perpetual $1850 \mathrm{AD}$ conditions $\left(\mathrm{PI}_{\mathrm{EQ}}\right)$ as reference state for the glacial simulations (in agreement with the PMIP protocol).

- Four MW simulations with different ice sheet topographies (Fig. 1, and Sect. 2.3).

- Two LGM simulations with different ocean surface forcings that represent a meta-stable state $\left(\mathrm{LGM}_{\mathrm{MS}}\right)$ and the final equilibrium state $\left(\mathrm{LGM}_{\mathrm{EQ}}\right)$. The ocean surface forcing differs especially in the North Atlantic with much lower SSTs and more extensive sea ice cover in the equilibrium state (Brandefelt and Otto-Bliesner, 2009).

In addition, a present-day CCSM4 simulation using transient forcings and observational SST and sea ice data for the period 1971 to 2000 (hereafter $\mathrm{PD}_{\mathrm{TR}}$ ) is conducted (see Hurrell et al. (2008) for information on the SST and sea ice data and Gent et al. (2011) for the external forcing). This simulation is compared with reanalysis data of the same period (ERA-40; Uppala et al., 2005) to shed light on the biases of the atmospheric CCSM4 model and with $\mathrm{PD}_{\mathrm{EQ}}$ to quantify the impact of the deviating ocean surface conditions (fully coupled simulated versus observed).

\subsection{Boundary conditions}

For all glacial experiments the boundary conditions are equivalent to the $\mathrm{PI}_{\mathrm{EQ}}$ simulation except for: (i) the Earth's orbital parameters, (ii) the concentrations of atmospheric greenhouse gases, (iii) the topography and the coastlines, (iv) the vegetation and the soil type, and (v) the prescribed SST and sea ice fields.

The values for the Earth's orbital parameters are calculated according to Berger (1978). The influence of the different orbital parameters between present-day and preindustrial is negligible. Compared with today, the solar radiation for the LGM is reduced in both hemispheres during their respective summer with the largest values (up to $14 \mathrm{~W} \mathrm{~m}^{-2}$ lower) found in the high-latitudes. For the MW the anomalies are generally larger (up to $30 \mathrm{~W} \mathrm{~m}^{-2}$ ) with lower insolation occurring from March to June (December to April) in the Northern (Southern) Hemisphere and a nearly global positive anomaly centred around September/October. The glacial concentrations of $\mathrm{CO}_{2}, \mathrm{CH}_{4}$ and $\mathrm{N}_{2} \mathrm{O}$ are based on ice core measurements (Schilt et al., 2010 and B. Bereiter, personal communication, 2012 for MW; PMIP protocol for LGM; http://www-lsce.cea.fr/pmip2/). The resulting change of the total global radiative forcing relative to preindustrial is $-2.89 \mathrm{~W} \mathrm{~m}^{-2}$ and $-2.21 \mathrm{~W} \mathrm{~m}^{-2}$ for LGM and MW, respectively (estimated according to IPCC (2001, Table 6.2); the increase from preindustrial to present-day is $+1.69 \mathrm{~W} \mathrm{~m}^{-2}$.

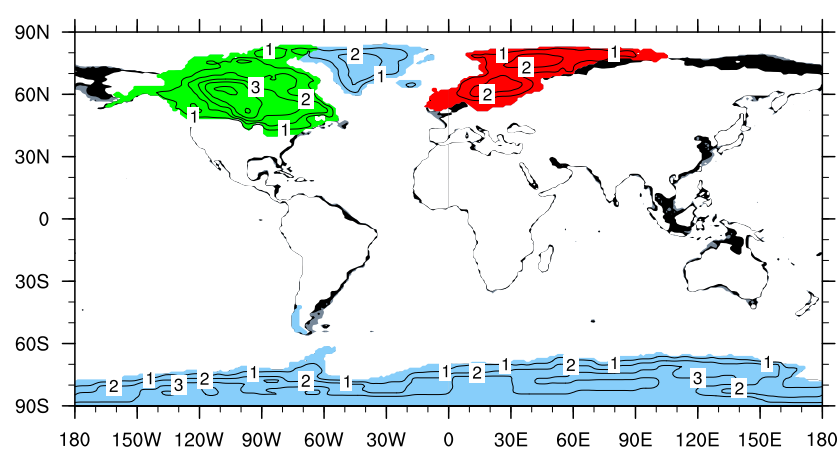

Fig. 1. LGM ice sheet extent (colour shadings: red and green for the Fennoscandian and Laurentide ice sheet, respectively, and light blue for Greenland and Antarctica) and thickness (contours, interval $1 \mathrm{~km}$ ), and additional land areas in MW (black) and LGM (black and gray). The coastlines and ice sheets for LGM are based on ICE-5G (Peltier, 2004). The shift of the coastlines (shown as the boundary of $50 \%$ landfraction) corresponds to a sea-level change of $80 \mathrm{~m}(\mathrm{MW})$ and $120 \mathrm{~m}$ (LGM) with respect to today.

The topography and the coastlines for all glacial simulations are based on the ICE-5G reconstruction (Peltier, 2004) and are illustrated in Fig. 1. For the LGM the topography is calculated as the model's present day topography, plus the spatially smoothed difference of Peltier's present day and LGM values. The sea level is lowered by about $120 \mathrm{~m}$ with respect to the modern level except for the Caspian Sea which is kept at its present-day extent and the coastal line is adjusted accordingly.

For the MW, the ice sheet extent and even more so its thickness are much more uncertain and, therefore, due to a lack of better data, the ICE-5G is used as a starting point for the construction of the ice sheet and the topography. In the four MW simulations, the sea level is lowered by $80 \mathrm{~m}$ (Siddall et al., 2008) and the spatial extent of the LGM ice sheet is maintained, while the thickness is adapted individually. In $\mathrm{MW}_{\mathrm{LGM}}$, which is used as a sensitivity experiment for the orbital and greenhouse gases (GHGs) forcings, the original LGM ice sheet height is applied. In the other three MW simulations, the total ice volume is increased by only $2 / 3$ of the LGM change with the following spatial distributions (see Table 1 for the exact numbers): (i) in $\mathrm{MW}_{\mathrm{LIN}}$ all ice sheet heights are increased linearly, (ii) in $\mathrm{MW}_{\mathrm{FS}}$ the Fennoscandian ice sheet is set at $1 / 3$ of its LGM height with more increase elsewhere, and (iii) in $\mathrm{MW}_{\mathrm{LT}}$ the Laurentide ice sheet has a much lower surface elevation compared with LGM.

The vegetation and the soil type in the glacial simulation are prescribed to the preindustrial distribution except for the additional land areas and the regions that are covered by the grown ice sheet. In the additional land cells vegetation and soil types are set to the mean values of nearby cells and in the ice covered regions the model's standard value for such conditions are used. 


\section{Evaluation}

Here, the model's ability to generate a reasonable climate state both in the past and present is investigated. To do so we briefly compare the present-day simulations with reanalysis data and the LGM simulations with proxy reconstructions for Europe (Wu et al., 2007). This allows identifying biases that have to be considered in the interpretation of the results of the sensitivity experiments.

\subsection{Present-day climate state}

We focus on the surface air temperature (SAT) and precipitation in the two present-day simulations which are compared to the monthly mean output of the years 1971-2000 of the ERA-40 reanalysis data (Uppala et al., 2005) interpolated to the $0.9 \times 1.25^{\circ}$ resolution of the CCSM4 output.

The global mean SAT in $\mathrm{PD}_{\mathrm{TR}}$ resembles the ERA-40 data with respect to the seasonal cycle and the interannual variability, but it shows a negative bias of $0.3^{\circ} \mathrm{C}$. In the North Atlantic and European region, which is of interest in this study, the SAT exhibits positive biases over most of Europe, southwestern Russia and Northern Greenland and negative biases over Scandinavia, Northern Africa and around the Hudson Bay, which generally do not exceed $\pm 3{ }^{\circ} \mathrm{C}$ (not shown). In the $\mathrm{PD}_{\mathrm{EQ}}$ simulation, the global mean $\mathrm{SAT}$ is $-0.6^{\circ} \mathrm{C}$ colder than in ERA-40 due to the too low SST introduced through the fully coupled CCSM3 simulation (Large and Danabasoglu, 2006). Over the continents the SAT pattern in $\mathrm{PD}_{\mathrm{EQ}}$ is similar to the one in $\mathrm{PD}_{\mathrm{TR}}$.

The global mean precipitation in $\mathrm{PD}_{\mathrm{TR}}$ and $\mathrm{PD}_{\mathrm{EQ}}$ is about $10 \%$ less than in ERA-40. However, the precipitation in ERA-40 is known to be excessive especially over the tropical oceans (Uppala et al., 2005, and references therein). In the North Atlantic region, both simulations exhibit similar patterns with mostly positive anomalies in arid regions and negative anomalies in humid areas, and a slight positive precipitation bias (up to $1 \mathrm{~mm} \mathrm{day}^{-1}$ ) in Northern Europe (not shown).

Overall, SAT and precipitation are simulated reasonably well and the SST biases introduced through CCSM3 do not seem to have a dominant impact on the present-day European precipitation.

\subsection{LGM climate state}

Before evaluating the two LGM simulations, we investigate our reference simulation $\left(\mathrm{PI}_{\mathrm{EQ}}\right)$ with respect to the $\mathrm{PD} \mathrm{EQ}_{\mathrm{E}}$ simulation. The global mean temperature is $1.3^{\circ} \mathrm{C}$ lower with stronger reductions at high-latitudes. It is not surprising that the global mean SAT difference between $\mathrm{PI}_{\mathrm{EQ}}$ and $\mathrm{PD} \mathrm{EQ}$ is much larger than that derived from observations, as the two simulations represent equilibrated states and the transient climate is not in equilibrium. In contrast to the temperature, the global mean precipitation in $\mathrm{PI}_{\mathrm{EQ}}$ is close to its value in
$\mathrm{PD}_{\mathrm{EQ}}$ and the precipitation pattern is not significantly altered except for a weak decrease polewards of $60^{\circ} \mathrm{N}$.

The SAT differences between $\mathrm{PI}_{\mathrm{EQ}}$ and $\mathrm{LGM}_{\mathrm{MS}}$ and $\mathrm{LGM}_{\mathrm{EQ}}$ are consistent with other models regarding the global means $\left(4.5^{\circ} \mathrm{C}\right.$ for $\mathrm{LGM}_{\mathrm{MS}}$ and $5.6^{\circ} \mathrm{C}$ for $\left.\mathrm{LGM}_{\mathrm{EQ}}\right)$ and the large-scale patterns (Braconnot et al., 2007). Note, however, that the SAT changes in the northern North Atlantic are $5-10^{\circ} \mathrm{C}$ larger for $\mathrm{LGM}_{\mathrm{EQ}}$ (and with reduced amplitude also for $\mathrm{LGM}_{\mathrm{MS}}$ ) than suggested by the multi-model mean of Braconnot et al. (2007), presumably due to low SSTs and the very extended sea ice cover (Otto-Bliesner et al., 2006a; Brandefelt and Otto-Bliesner, 2009).

In agreement with the overall lower mean temperatures, the global mean precipitation is reduced by $10 \%$ for $L_{G M}$ and $12 \%$ for $\mathrm{LGM}_{\mathrm{EQ}}$ compared with $\mathrm{PI}_{\mathrm{EQ}}$. The large-scale precipitation anomaly patterns are similar in both simulations and consistent with the multi-model mean of Braconnot et al. (2007).

For a more detailed evaluation in Europe the simulated LGM climate is compared to the proxy reconstruction from Wu et al. (2007) which is based on an inverse vegetation modelling approach using pollen data. The reconstruction offers temperature and precipitation anomalies with respect to the 1970s for the coldest (January) and warmest (July) month and for the annual mean. 32 sites in the European region are selected and compared with the simulated patterns of $\mathrm{LGM}_{\mathrm{MS}}-\mathrm{PD}_{\mathrm{EQ}}$ and $\mathrm{LGM}_{\mathrm{EQ}}-\mathrm{PD}_{\mathrm{EQ}}$.

For the coldest month, the cooling is underestimated for most of the southern locations, while it is overestimated for the northern part (Fig. 2a and b). Nevertheless, the temperature difference between the simulations and the reconstruction is less than $5{ }^{\circ} \mathrm{C}$ for the majority of the proxy sites and only at a few locations the simulated temperature is outside the $90 \%$ confidence interval of the reconstruction. In contrast, the simulated SATs for the warmest month are not consistent with the reconstructed ones at most locations (Fig. 2c and d); so the simulations' results for summer should be interpreted with caution. For the annual mean SAT, the simulations are close to the reconstruction in the Mediterranean region, but overestimate the temperature change in the far northeast (Fig. 2e and f). Note that in both seasons and for the annual mean strong temperature differences at nearby proxy sites, which are likely related to locale impact factors, have no correspondence in the simulated pattern.

The reconstructed precipitation indicates a tendency towards drier conditions over Europe for the annual mean, as well as the coldest and warmest month, while the simulations exhibit a more heterogeneous pattern with a band between $35^{\circ}$ to $50^{\circ} \mathrm{N}$ of increased precipitation in January and one between $50^{\circ}$ to $60^{\circ} \mathrm{N}$ in July (Fig. 3). Due to the large uncertainties, the simulated precipitation anomalies are consistent with the reconstruction at most locations. Note, however, that the strongly increased winter precipitation in Spain has no analogue in the reconstruction. 

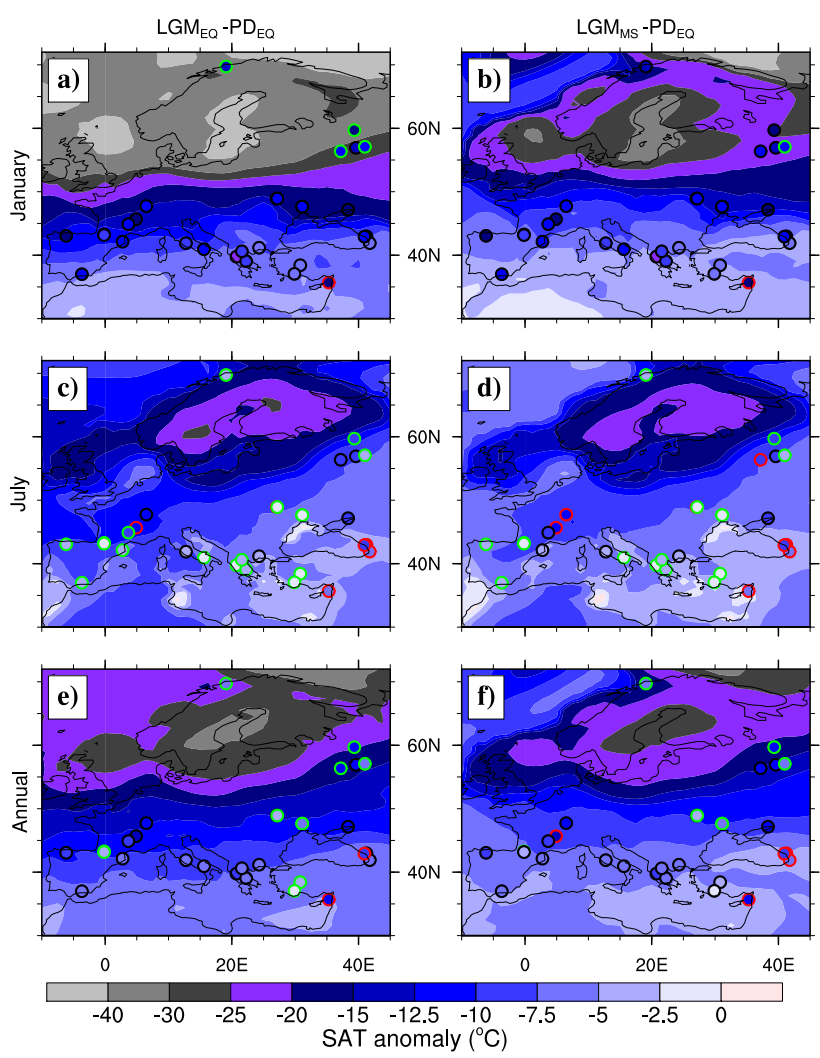

Fig. 2. SAT anomalies with respect to $P D_{E Q}$ for $L G M E Q$ (left) and $\mathrm{LGM}_{\mathrm{MS}}$ (right) for the coldest month (January, a and b), the warmest month (July, $\mathbf{c}$ and $\mathbf{d}$ ), and the annual mean (e and $\mathbf{f}$ ). The coloured circles are estimated temperature anomalies based on proxy data (Wu et al., 2007) with a red (green) border indicating significantly stronger (weaker) negative anomalies than at the closest grid cell of the model (outside the $90 \%$ confidence interval of Wu et al., 2007).

Overall, no evidence is found that one of the two LGM simulations leads to a much better agreement with the reconstruction, as the SATs agree better in $\mathrm{LGM}_{\mathrm{MS}}$ while precipitation agrees more in $\mathrm{LGM}_{\mathrm{EQ}}$.

\section{Impact on temperature and precipitation}

The impacts of the glacial boundary conditions on temperature and precipitation in the North Atlantic region are presented using three subsets of the simulations. First, the topographic effect, which is the most important one, is investigated based on the four MW simulations. Second, the impact of the prescribed SSTs and sea ice is analysed by comparing $\mathrm{LGM}_{\mathrm{MS}}$ and $\mathrm{LGM}_{\mathrm{EQ}}$. Third, the influence of the radiative forcing is investigated using the $\mathrm{MW}_{\mathrm{LGM}}$ and the equilibrium LGM simulation.
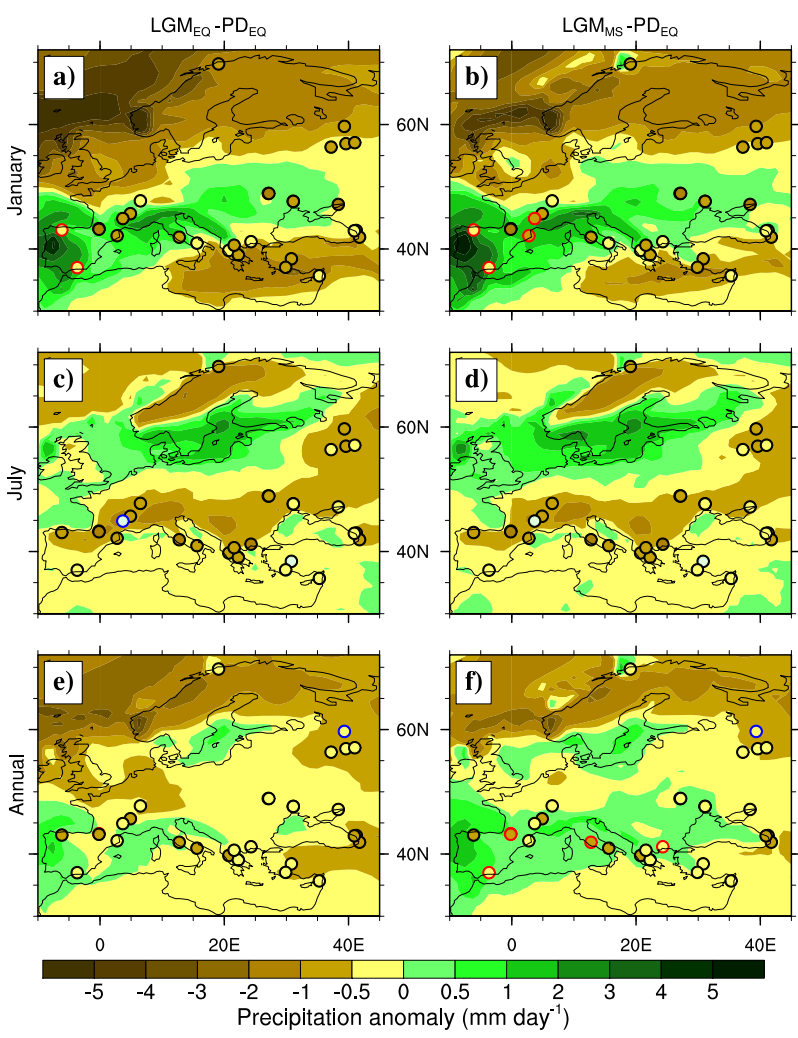

Fig. 3. As Fig. 2, but for precipitation.

\subsection{Sensitivity to ice sheet height}

The global mean SAT reduction from the $\mathrm{PI}_{\mathrm{EQ}}$ to the MW simulations is in the range of $4.7-4.8^{\circ} \mathrm{C}$. The large-scale temperature anomalies are similar in all simulations and resemble the ones that are found for the LGM. Significant (at the $5 \%$ level) SAT differences between the MW simulations occur over the ice sheets, in continental regions downstream of the ice sheets (especially in winter), and - only in winter - between $40^{\circ}$ and $50^{\circ} \mathrm{N}$ across the North Atlantic (not shown). Over the ice sheets, they are a direct effect of the changed altitude (lapse rate feedback), while the other differences are expected to be a consequence of changed atmospheric dynamics.

The global mean precipitation is virtually identical in all MW simulations. Regarding winter precipitation, however, a strong impact of the height of the Laurentide ice sheet is evident in the North Atlantic region. In contrast to the generally drier conditions, positive precipitation anomalies are found in the mid-latitudes that are more pronounced in the simulations with a stronger elevated Laurentide ice sheet (Fig. 4a-d). In $\mathrm{MW}_{\mathrm{LT}}$ (Laurentide ice sheet height at $46 \%$ of the LGM value) significant (at the $5 \%$ level) positive precipitation anomalies are found in the western North Atlantic between $30^{\circ} \mathrm{N}$ to $40^{\circ} \mathrm{N}$ and $40^{\circ} \mathrm{W}$ to $70^{\circ} \mathrm{W}$ and a few small patches around Spain. In $\mathrm{MW}_{\mathrm{LIN}}$ (height at $67 \%$ ) 

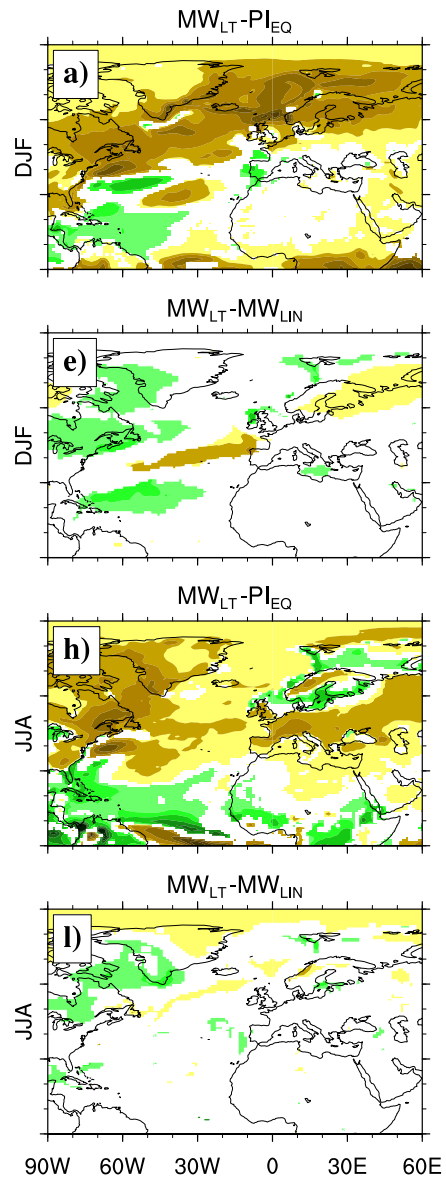
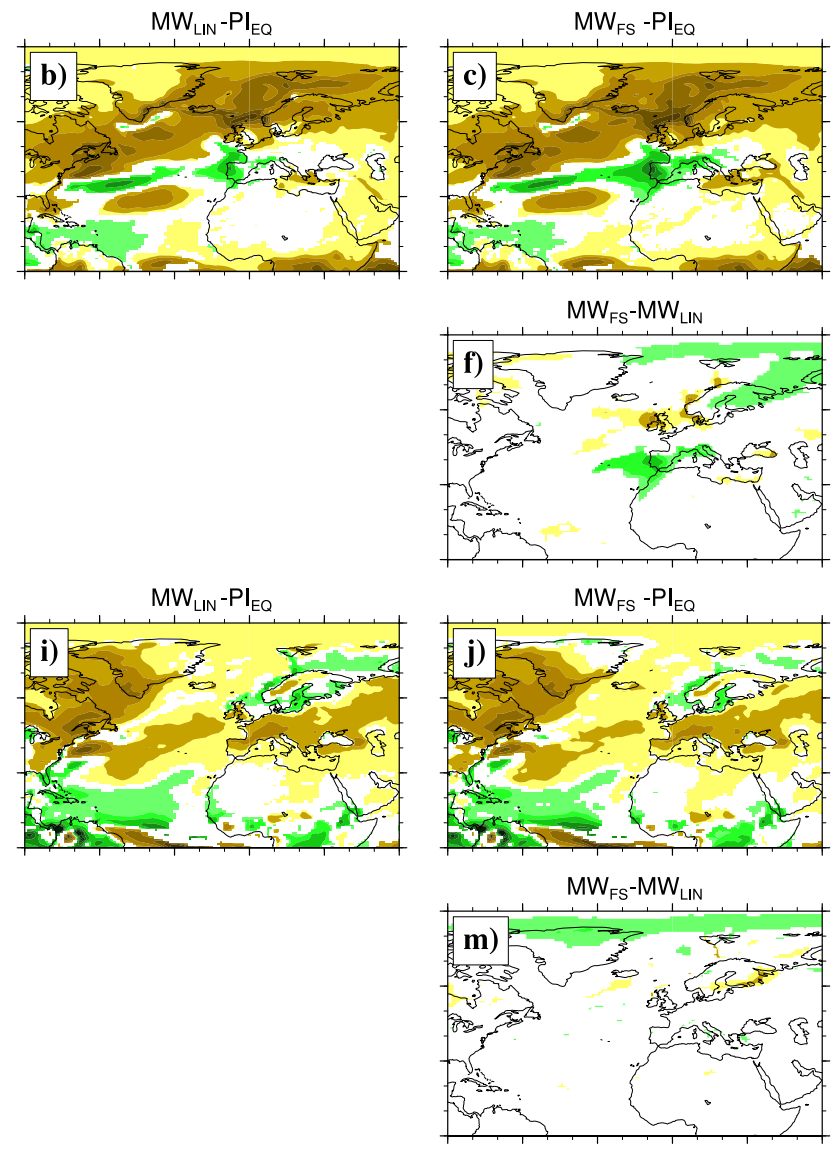

$90 \mathrm{~W} 60 \mathrm{~W} 30 \mathrm{~W}$
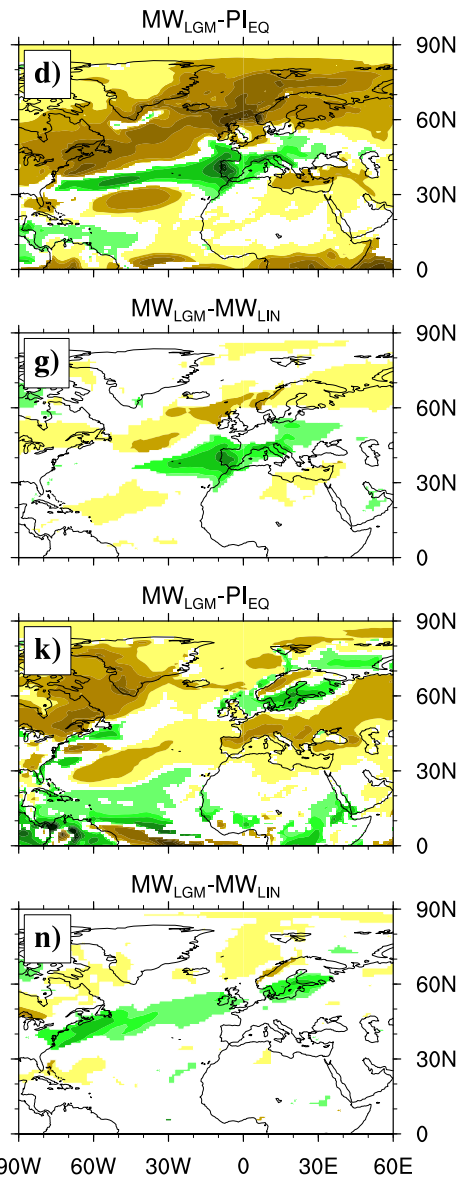

$\begin{array}{lllllllllllll}-5 & -4 & -3 & -2 & -1 & -0.5 & 0 & 0.5 & 1 & 2 & 3 & 4 & 5\end{array}$

Fig. 4. Winter (DJF, upper half) and summer (JJA, lower half) precipitation anomalies with respect to $\mathrm{PI}_{\mathrm{EQ}}(\mathbf{a}-\mathbf{d}$ and $\mathbf{h}-\mathbf{k})$ and to $\mathrm{MW}$ LIN (e-g and l-n) for all MW simulations. Only values that are statistically significant at the $5 \%$ level based on the two-sided Student's t-test are coloured.

the anomalies are spatially more extended and in $\mathrm{MW}_{\mathrm{FS}}$ (height at $76 \%$ ) they form a continuous band from the eastern coast of North America to southeastern Europe, which is even more pronounced in $\mathrm{MW}_{\mathrm{LGM}}$ (height at $100 \%$ ). Note that positive winter precipitation anomalies in southwestern Europe and the adjacent Atlantic are a common feature of LGM simulations (ice sheet heights as in $\mathrm{MW}_{\mathrm{LGM}}$ ) of different models (Laine et al., 2009) and are also found in CCSM3 (Strandberg et al., 2011).

Additionally, precipitation anomalies in other areas consistently change with the height of the Laurentide ice sheet. A lower altitude of the Laurentide ice sheet corresponds to a precipitation increase over the eastern part of its slope, in the Labrador Sea, in the North Atlantic at $20^{\circ} \mathrm{N}$ and north of Great Britain (Fig. 4e-g). The impact of the Fennoscandian ice sheet is less pronounced and mainly affects the precipitation at its southeastern slope (increased precipitation in simulations with a lower altitude of this ice sheet).
For summer, the precipitation differences between the four simulations are much smaller and not significant for most regions (Fig. $4 \mathrm{~h}-\mathrm{n}$ ). The few significant changes point to a similar, but much weaker impact of the Laurentide ice sheet as in winter.

\subsection{Sensitivity to the sea surface temperature and sea ice}

As expected from the prescribed ocean surface forcing, the strongest discrepancies between the two LGM simulations occur in the North Atlantic region for the winter SATs. In $\mathrm{LGM}_{\mathrm{EQ}}$ the winter sea ice extends as far south as $40^{\circ} \mathrm{N}$ and the Nordic Seas are widely covered by ice leading to a strong regional decrease of SATs compared to $\mathrm{PI}_{\mathrm{EQ}}$. In contrast, the less extensive southward sea ice extent in $\mathrm{LGM}_{\mathrm{MS}}$ leads to a much less pronounced cooling, so that the two LGM simulations differ by up to $30^{\circ} \mathrm{C}$ over the ocean especially in the 


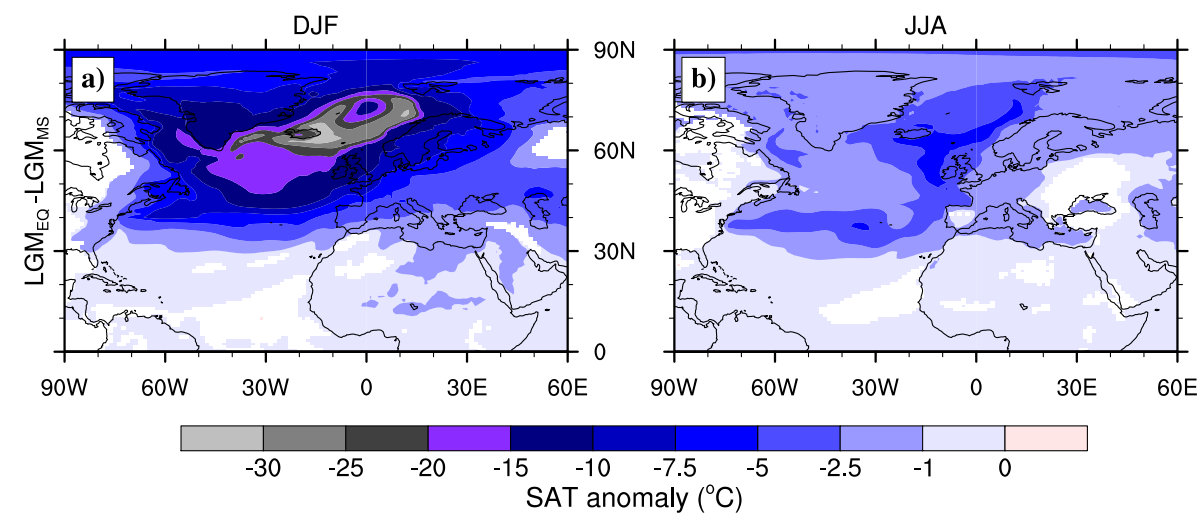

Fig. 5. Winter (DJF, a) and summer (JJA, b) SAT difference between $\mathrm{LGM}_{\mathrm{EQ}}$ and $\mathrm{LGM}_{\mathrm{MS}}$. Only values that are statistically significant at the $5 \%$ level based on the two-sided Student's t-test are coloured.

Nordic Seas (Fig. 5a). As a further consequence, the cooling in Europe which lies downstream of the strong anomaly is less pronounced in $\mathrm{LGM}_{\mathrm{MS}}$. For JJA the temperature differences are much weaker (generally less than $5^{\circ} \mathrm{C}$ ), but they are still statistically significant at the $5 \%$ level (Fig. 5b).

The precipitation anomaly patterns share the main characteristics in the North Atlantic region and strongly resemble the ones for $\mathrm{MW}_{\mathrm{LGM}}$ - both in summer and winter (Fig. 6ad). The strongest differences between the two simulations occur during winter in the northern North Atlantic and in the Nordic Seas and can be related to the reduced evaporation due to the changed ocean surface conditions (Fig. 6e). The DJF precipitation in LGM $_{\mathrm{LGM}}$ is also slightly decreased over parts of the Mediterranean, while an increase is found at the lee side of the Fennoscandian ice sheet. In summer, most of the differences are not significant (at the 5\% level) except for the area from the eastern coast of Greenland to central and eastern Europe where in $\mathrm{LGM}_{\mathrm{EQ}}$ slightly drier conditions prevail (Fig. 6f).

Overall, the different ocean surface forcings for $L_{G M}$ and $\mathrm{LGM}_{\mathrm{EQ}}$ do not fundamentally alter the large-scale precipitation anomaly patterns compared to $\mathrm{PI}_{\mathrm{EQ}}$, even though the impact on winter SATs is strong. The main difference between the simulations is a modulation of the amplitude in several regions, e.g., in the Nordic Seas.

\subsection{Sensitivity to the radiative forcing}

The global mean SAT in $\mathrm{MW}_{\mathrm{LGM}}$ is $0.8^{\circ} \mathrm{C}$ higher than in $\mathrm{LGM}_{\mathrm{EQ}}$ and the strongest differences are found in the North Atlantic region during winter. The prescribed sea ice is spatially less extended in $\mathrm{MW}_{\mathrm{LGM}}$, which results in a SAT difference pattern that is similar to the one between the two LGM simulations, but with reduced amplitude especially around Newfoundland (not shown). Due to the strong ocean surface differences north of $40^{\circ} \mathrm{N}$, which represent the forcing impacts in CCSM3, it is impossible to estimate the direct effect of the orbital and GHGs changes on the CCSM4 atmosphere in this region. Elsewhere the changes correspond to the forcing, i.e., the Southern Hemisphere is slightly cooler in $\mathrm{MW}_{\mathrm{LGM}}$ due to a strong reduction of solar insolation that overcompensates the increased GHGs forcing. For JJA, the SATs are globally higher in MW $_{\text {LGM }}$ in agreement with the higher insolation and the increased GHG concentrations.

Regarding precipitation, the pattern $\mathrm{LGM}_{\mathrm{EQ}}-\mathrm{MW}_{\mathrm{LGM}}$ resembles $\mathrm{LGM}_{\mathrm{EQ}}-\mathrm{LGM}_{\mathrm{MS}}$ in winter (with less pronounced differences around Newfoundland as for SAT), while for JJA especially the tropics show major differences (Fig. $6 \mathrm{~g}$ and h). Thus, the effect of the changed radiative forcing in $\mathrm{MW}_{\mathrm{LGM}}$ globally affects SATs and also the precipitation in the tropics, but it is not possible to directly address its impact on the precipitation in the North Atlantic region as the major differences seen in this region can be at least partly related to changes in the prescribed SSTs and sea ice.

\section{Importance of the atmospheric dynamics}

Other studies have shown that the DJF precipitation anomalies in the LGM simulations are related to changes in the storminess (Laine et al., 2009) and for CCSM3 the increased mid-latitude LGM precipitation is associated with a southward shift of the Atlantic storm track (Otto-Bliesner et al., 2006a; Strandberg et al., 2011). To investigate the impact of the boundary conditions on the synoptic scale variability in our simulations, two different methods are considered: an Eulerian measure, which is defined as the bandpass filtered (2.5-6 days) standard deviation of the $500 \mathrm{hPa}$ geopotential height (Blackmon, 1976) and a Lagrangian method, where the storminess is estimated based on the trajectories of low-pressure systems at $1000 \mathrm{hPa}$ geopotential height (Blender et al., 1997). Both methods are applied to 6-hourly data. For the Lagrangian approach only low-pressure systems are considered that have a life-time of at least one day and whose mean gradients around the minimum (radius of $1000 \mathrm{~km}$ ) exceed $100 \mathrm{gpm}$ per $1000 \mathrm{~km}$ during the life cycle. 

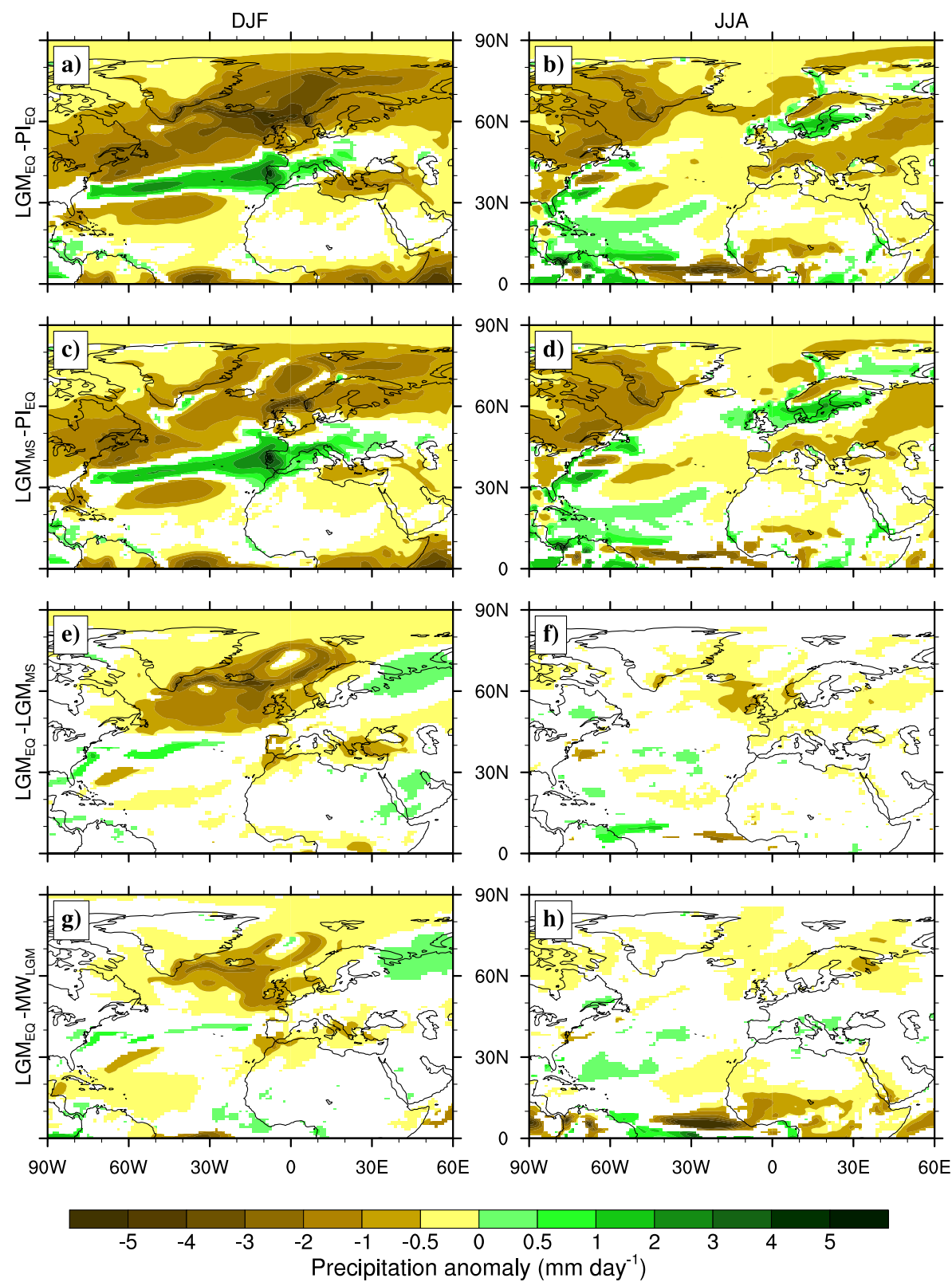

Fig. 6. Winter (DJF, left) and summer (JJA, right) precipitation anomalies for LGM $\mathrm{EQ}_{\text {(a and } \mathbf{b}) \text { and LGM }}$ (c) and d) with respect to $\mathrm{PI}_{\mathrm{EQ}}$, and the differences between $\mathrm{LGM}_{\mathrm{EQ}}$ and $\mathrm{LGM}_{\mathrm{MS}}(\mathbf{e}$ and $\mathbf{f})$ and $\mathrm{LGM}_{\mathrm{EQ}}$ and $\mathrm{MW}_{\mathrm{LGM}}(\mathbf{g}$ and $\mathbf{h})$. Only the values that are statistically significant at the $5 \%$ level based on the two-sided Student's t-test are coloured.

Additionally, cyclones in regions where the terrain height is above $1000 \mathrm{~m}$ are excluded due to potential extrapolation errors in the $1000 \mathrm{hPa}$ geopotential height field.

For $\mathrm{PI}_{\mathrm{EQ}}$ the storm track and the cyclone center density patterns are similar to the ones found for present-day observations (Fig. 7a; e.g. Raible et al., 2008). The Eulerian measure exhibits a maximum over Newfoundland extending eastwards to the ocean and the cyclone center density is high in the region from the northwestern North Atlantic to the south of Greenland, around Iceland and in the Nordic Seas.
In the glacial simulations the anomalies for both measures indicate a southward shift with a decrease in the north and northwestern part and an increase in the south (Fig. 7b-h). For the Eulerian measure the anomalies form a dipole like structure with the minimum located around the southern tip of Greenland and the maximum lying west of Spain while the cyclone center density indicate a similar pattern, but shifted to the north. Generally, the anomalies are strongest when using the full LGM ice sheet height and decrease with a lower Laurentide ice sheet. 

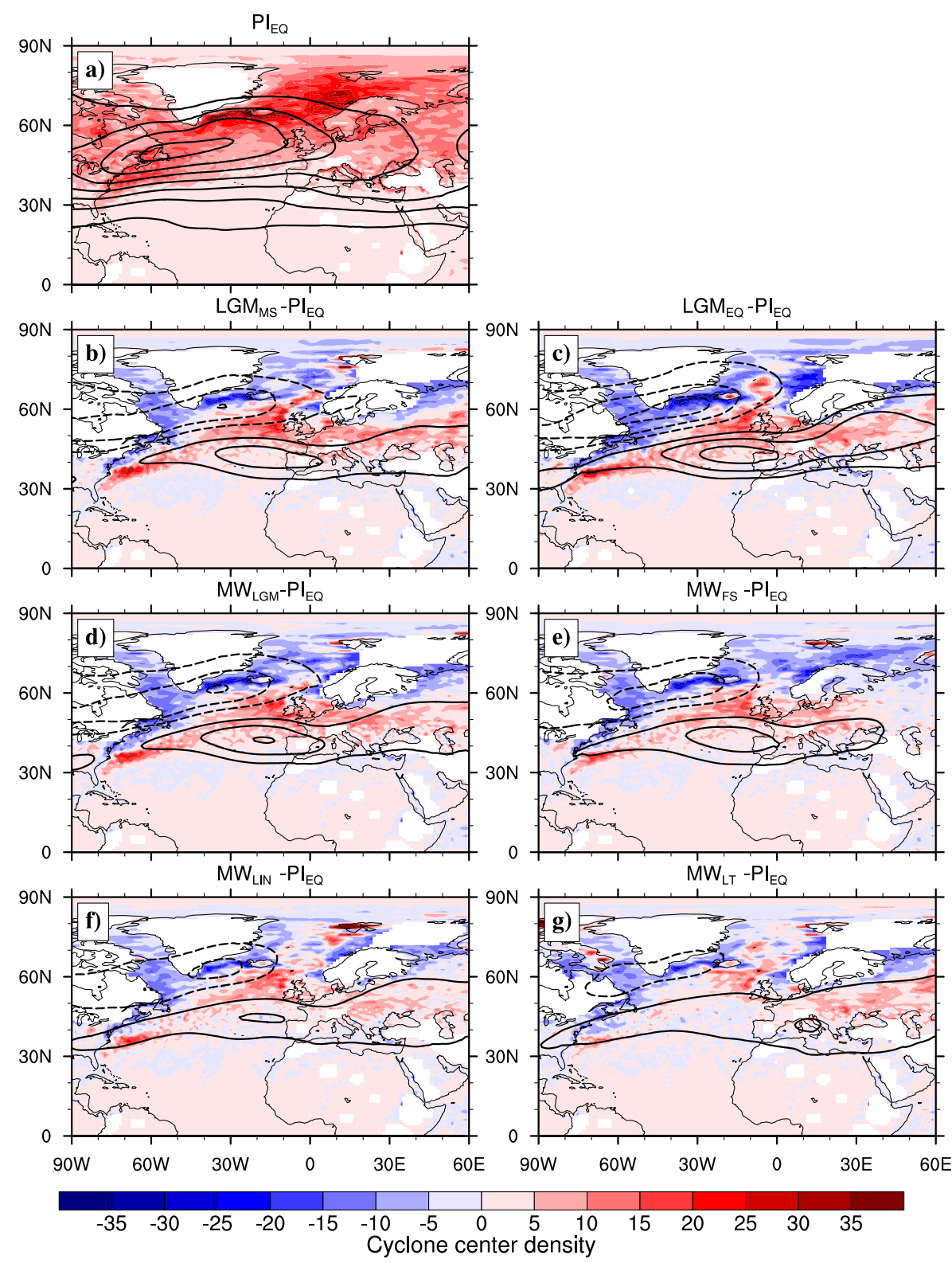

Fig. 7. Synoptic activity in winter (DJF) using two different measures, namely cyclone center density (colours, only values where the altitude is below $1000 \mathrm{~m}$ ) and band-pass filtered (2.5 to 6 days) standard deviation of the $500 \mathrm{hPa}$ geopotential height (contours). The mean value for $\mathrm{PI}_{\mathrm{EQ}}$ are shown in (a) while in (b-g) the anomalies of the different glacial simulations with respect to $\mathrm{PI}_{\mathrm{EQ}}$ are presented. The contour interval is every $10 \mathrm{gpm}$, negative contours are dashed and the zero contour line is omitted.

Some differences between the $\mathrm{LGM}_{\mathrm{MS}}$, $\mathrm{LGM}_{\mathrm{EQ}}$ and $\mathrm{MW}_{\mathrm{LGM}}$ simulations are notable suggesting an influence of the ocean surface forcing. In $\mathrm{LGM}_{\mathrm{EQ}}$ - and to a lesser degree in $\mathrm{MW}_{\mathrm{LGM}}$ - the amplitudes of the anomalies over the North Atlantic are increased compared to $\mathrm{LGM}_{\mathrm{MS}}$. Such a behaviour is expected as a consequence of the stronger SAT reduction in the northern part which increases the meridional temperature gradient at the surface leading to enhanced lower-level baroclinicity.
In the case of a lower Laurentide ice sheet the anomalies are not only weaker, but also changed in their structure (Fig. 7e-g). The dipole like pattern of the bandpass filtered standard deviation of the $500 \mathrm{hPa}$ geopotential height is reduced in $\mathrm{MW}_{\mathrm{FS}}$ and $M \mathrm{MW}_{\mathrm{LIN}}$ and nearly vanishes in $\mathrm{MW}_{\mathrm{LT}}$. For the latter, the remaining anomalies over the Atlantic are located more to the north. Similarly, the positive anomalies of the cyclone center density are shifted to the north and reduced to patches in the western Atlantic at $35^{\circ} \mathrm{N}$ and the region around the Iceland-Scotland ridge (again more so in 
$\mathrm{MW}_{\mathrm{LT}}$ than in $\mathrm{MW}_{\mathrm{LIN}}$ and $\left.\mathrm{MW}_{\mathrm{FS}}\right)$. In contrast, a clear impact of the Fennoscandian ice sheet is only evident in the very eastern $\left(30-60^{\circ} \mathrm{E}\right)$ mid-latitudes where the anomalies mostly vanish for $\mathrm{MW}_{\mathrm{FS}}$.

To complete the analysis of the atmospheric dynamics, the changes in the upper troposphere are investigated. To do so the zonal wind at $200 \mathrm{hPa}$ - the height of the jet stream maximum - is examined. $\mathrm{In}_{\mathrm{PI}} \mathrm{EQ}$ the jet develops two branches in the North Atlantic the so-called eddy driven jet which extends from the eastern coast of North America to Great Britain and the subtropical jet which is located at $20^{\circ}$ to $30^{\circ} \mathrm{N}$ across the entire sector with the maximum wind speed in its eastern part (Fig. 8a). In the glacial simulations this pattern strongly changes with increasing height of the Laurentide ice sheet: the southern part of the jet is weakened while the wind speed in the central North Atlantic is strongly increased (Fig. 8b-g). This corresponds to a strengthening and southward extension of the eddy-driven jet and - especially in $\mathrm{LGM}_{\mathrm{MS}}, \mathrm{LGM}_{\mathrm{EQ}}$ and $\mathrm{MW}_{\mathrm{LGM}}$ - to an interruption of the subtropical jet over the Atlantic. As for the storm and cyclone tracks the changes are amplified by the increased meridional temperature gradient in $\mathrm{LGM}_{\mathrm{EQ}}$. In simulations with a lower Laurentide ice sheet the anomalies are not only weaker, but also shifted to the north. Over the Fennoscandian ice sheet we see an enhanced zonal wind in $\mathrm{MW}_{\mathrm{LT}}$, which is most pronounced in spring and autumn (not shown). Given the available simulations it is, however, not possible to determine whether this is a feature of the interplay between the two ice sheets or only related to the Fennoscandian one.

The atmospheric dynamics in summer is also changed, but not as strong as in winter. Both measures for the storminess indicate a tendency towards increased synoptic activity in the south and a decrease in the northwest which are stronger in the simulations with a high Laurentide ice sheet, but the jet stream is not displaced (not shown).

\section{Discussion and conclusions}

Using the ocean surface conditions of simulations with a fully coupled atmosphere-ocean general circulation model (CCSM3) as input to a higher resolved atmospheric general circulation model (CCSM4), we investigated the impact of different glacial boundary conditions on the temperature, precipitation and atmospheric dynamics in the North Atlantic region. This two-model approach is selected as it is a computationally effective way to investigate the problem, especially because equilibrium simulations for the presentday, the preindustrial period and the LGM conducted with CCSM3 were already available (Otto-Bliesner et al., 2006a; Brandefelt and Otto-Bliesner, 2009).

However, the approach imposes new uncertainties as biases and shortcomings in the low-resolution simulations are introduced in the high-resolution CCSM4 and the ocean response to the applied atmospheric forcing within CCSM4 is neglected. Fortunately, the analysis has shown that even the strong differences between the ocean surface forcing in $\mathrm{LGM}_{\mathrm{MS}}$ and $\mathrm{LGM}_{\mathrm{EQ}}$ do not fundamentally alter the resulting large-scale patterns, but mainly affect the regional climate. Therefore, we conclude that the approach used in this study is reasonable even though the ocean surface in the CCSM4 simulations has potential deficiencies.

Before the differences between the glacial simulations are investigated, the model's ability to simulate present-day and LGM climates is evaluated. Even though in many regions temperature and precipitation in the model significantly differ from the reanalysis data for present-day (which is, however, partially attributed to problems in the reanalysis data, Uppala et al., 2005), these biases are much weaker than the anomalies between the recent past and the glacial states for the North Atlantic region. Therefore, we are confident that the glacial differences are not caused by biases that are already present in the present-day simulations. The glacial anomalies for summer should, however, be interpreted with caution as the amplitudes are generally smaller and - more importantly - the simulated July SATs for LGM are outside the confidence intervals of the reconstruction of $\mathrm{Wu}$ et al. (2007) at most locations. For winter, the LGM simulations mostly lie within the confidence intervals of the reconstruction with one exception over southwestern Europe. Note that the proxy data has a large confidence interval and that other models - including a regional one with higher resolution find also a precipitation increase over this region (Braconnot et al., 2007; Strandberg et al., 2011).

Even though the LGM simulations widely agree with the reconstruction, it is important to note that they include substantial uncertainties: the extent and altitude of the ice sheets are only approximations and several forcing factors are missing, e.g., changes of the vegetation cover and dust. Other studies have shown that for the LGM changed vegetation and dust can alter global SATs in the order of several tenth of a degree Celsius each (Jahn et al., 2005; Mahowald et al., 2006). An additional source of uncertainties is introduced through the prescribed ocean surface conditions which have several biases compared to reconstructions (Otto-Bliesner et al., 2006a; Brandefelt and Otto-Bliesner, 2009). The ocean surface biases are expected to be worse in the MW simulations, as the CCSM3 simulation for MW uses the LGM bathymetry and topography that do not represent the MW conditions correctly. However, the preferential intent of this study is not to simulate the climate for MW with the highest accuracy possible, but to investigate the sensitivity of the climate to different glacial boundary conditions. Thus, all of the MW simulations have to be understood as sensitivity experiments based on the MW state more than as accurate representations of the MW climate.

Our glacial experiments have shown that especially in winter the climate in the North Atlantic region is strongly influenced by the altitude of the Laurentide ice sheet. A high ice sheet (as in LGM) leads to a southward shift of the 

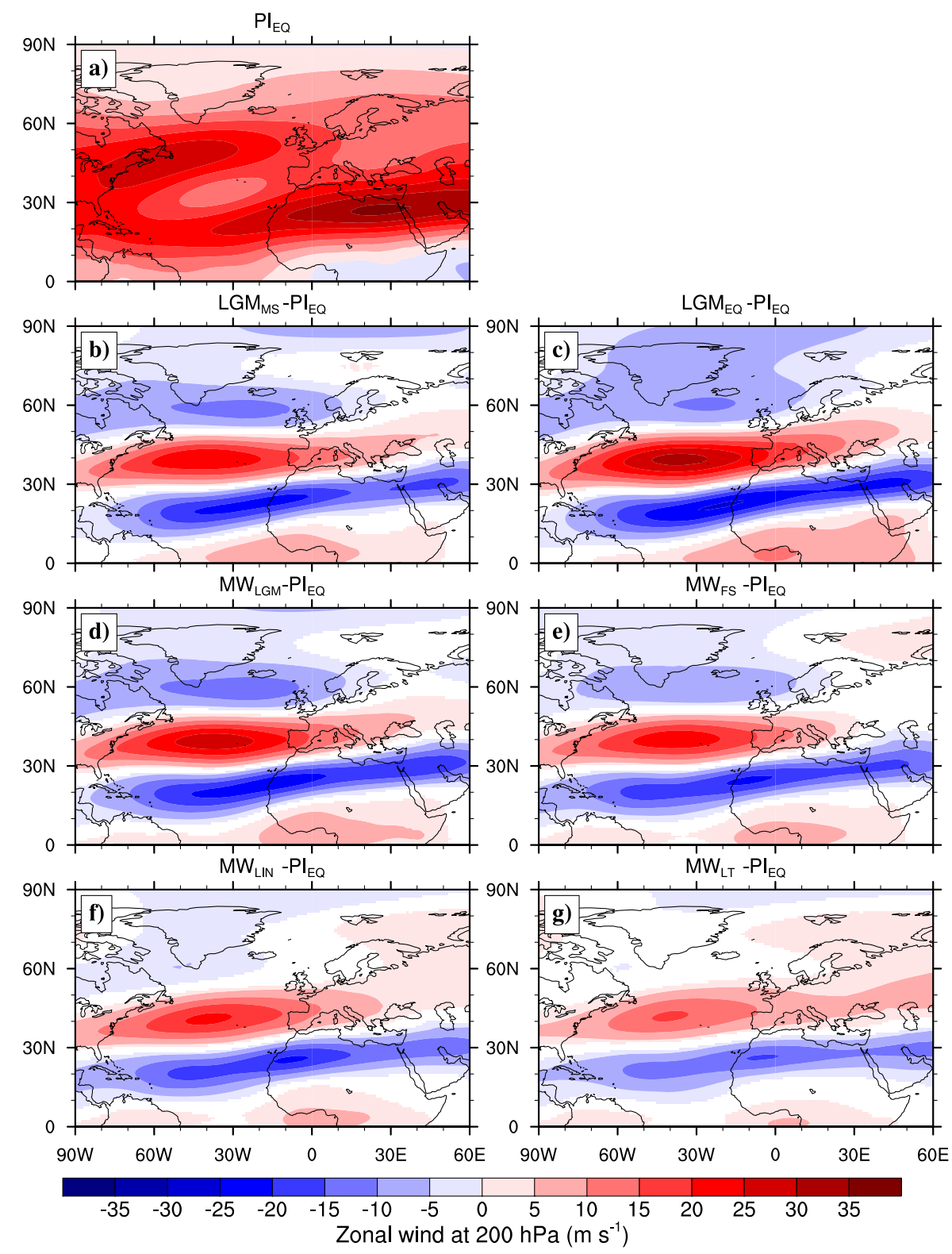

Fig. 8. Zonal wind at $200 \mathrm{hPa}$ for DJF. The mean value for $\mathrm{PI}_{\mathrm{EQ}}$ are shown in (a) while in (b-g) the anomalies of the different glacial simulations with respect to $\mathrm{PI}_{\mathrm{EQ}}$ are presented. For the anomalies only values that are statistically significant at the $5 \%$ level based on the two-sided Student's t-test are coloured.

eddy-driven jet stream and of the storm and cyclone center, which is more pronounced in the eastern part of the North Atlantic. This resembles findings of other PMIP simulations that exhibit a southeastward extension of the winter storm track (Kageyama et al., 1999; Laine et al., 2009). In our simulations, we find a direct relationship between changes in the storm track and precipitation anomalies in the North Atlantic region. However, our study is based on only one model and the results of Laine et al. (2009) suggest that such a relationship could be model-dependent. Note also that a meridional shift of the North Atlantic storm track in winter is not only found in simulations where the Laurentide ice sheet height is altered, but also when the topography of Greenland is changed - even though the mechanism is different (Dethloff et al., 2004; Petersen et al., 2004; Junge et al., 2005).

The analysis of the two LGM simulations with different ocean surface forcings shows that the observed atmospheric changes for a high Laurentide ice sheet are amplified when the meridional temperature gradient in the North Atlantic is increased. This result is consistent with Toracinta et al. (2004) who used a lower resolved atmospheric model forced either by the CLIMAP SST fields or by artificially adapted 
CLIMAP SST fields with a lower meridional temperature gradient. An analogue behaviour, namely a southward shift of the storm track in the North Atlantic, is also reported for a modelling study comparing the Little Ice Age (1550$1850 \mathrm{AD}$ ) with present-day which shows an increased meridional temperature gradient (Raible et al., 2007).

The impact of the radiative forcing difference between LGM and MW in the time slice experiments is dominated by the lower boundary conditions introduced by the fullycoupled CCSM3. Thus, the impacts on atmospheric dynamics and precipitation as well as the mechanism are similar to the ones for the ocean surface forcing.

This study contributes to the long history of scientific literature that investigates the impact of glacial topographic changes on the atmosphere (e.g. Manabe and Broccoli, 1985; Kutzbach and Guetter, 1986; Felzer et al., 1996; Kageyama and Valdes, 2000; Justino and Peltier, 2005; Pausata et al., 2011) by directly comparing the effects to the influence of other boundary conditions using a highly-resolved atmospheric general circulation model. Recently, a similar approach has been applied using a coupled atmosphere-ocean general circulation model, which also identified topographic changes as the dominant impact factor (Pausata et al., 2011). However, their study only considers LGM conditions, is based on a lower resolved atmosphere (horizontal resolution of $2.5 \times 3.75^{\circ}$ compared to $0.9 \times 1.25^{\circ}$ in this work), and does not address the impacts on precipitation.

In contrast to the results of Kageyama and Valdes (2000), the winter precipitation over the Fennoscandian ice sheet is not strongly changed by the height of the Laurentide ice sheet in our simulations. However, it is difficult to directly compare the results of the two studies. First, the Laurentide ice sheet is not completely removed in our simulations as it is in Kageyama and Valdes (2000) and, second, the height of the Fennoscandian ice sheet is also altered.

The positive precipitation anomaly over southern Europe that occurs in the simulations with a strongly elevated Laurentide ice sheet needs further discussion, as the regions affected also include the glaciers in the Pyrenees and the southern part of the Alps. Enhanced winter precipitation increases the accumulation of these glaciers and, thus, a high accumulation is expected in time periods as the LGM. While this is consistent with the alpine glaciers which reached their maximum advances broadly synchronous with the global LGM, major uncertainties remain for the Pyrenees where some chronologies indicate an earlier maximum (Hughes and Woodward, 2008; Thackray et al., 2008). However, a detailed analysis of the impacts of the simulated changes for glacier advances and retreats exceeds the scope of this work.

Acknowledgements. We gratefully acknowledge Niklaus Merz for valuable discussion. This work is funded by the Swiss Federal Nuclear Safety Inspectorate (ENSI). CCR is supported by the NCCR Climate and the EU project Past4Future (Grant number 243908. 2010-2014). Most simulations were performed at the
Swiss National Supercomputing Centre (CSCS) in Manno. Some simulations and model data were kindly made available by the NCAR and by Jenny Brandefelt. Constructive comments by two anonymous reviewers and Eric Wolff have improved the manuscript.

Edited by: E. Wolff

\section{References}

Berger, A. L.: Long-term variations of daily insolation and quarternary climatic changes, J. Atmos. Sci., 35, 2362-2367, 1978.

Blackmon, M. L.: Climatological Spectral Study of 500 Mb Geopotential Height of Northern Hemisphere, J. Atmos. Sci., 33, 16071623, 1976.

Blender, R., Fraedrich, K., and Lunkeit, F.: Identification of cyclone-track regimes in the North Atlantic, Q. J. Roy. Meteor. Soc., 123, 727-741, doi:10.1002/qj.49712353910, 1997.

Braconnot, P., Otto-Bliesner, B., Harrison, S., Joussaume, S., Peterchmitt, J.-Y., Abe-Ouchi, A., Crucifix, M., Driesschaert, E., Fichefet, Th., Hewitt, C. D., Kageyama, M., Kitoh, A., Laîné, A., Loutre, M.-F., Marti, O., Merkel, U., Ramstein, G., Valdes, P., Weber, S. L., Yu, Y., and Zhao, Y.: Results of PMIP2 coupled simulations of the Mid-Holocene and Last Glacial Maximum Part 1: experiments and large-scale features, Clim. Past, 3, 261277, doi:10.5194/cp-3-261-2007, 2007.

Brandefelt, J. and Otto-Bliesner, B. L.: Equilibration and variability in a Last Glacial Maximum climate simulation with CCSM3, Geophys. Res. Lett., 36, L19712, doi:10.1029/2009GL040364, 2009.

Collins, W. D., Bitz, C. M., Blackmon, M. L., Bonan, G. B., Bretherton, C. S., Carton, J. A., Chang, P., Doney, S. C., Hack, J. J., Henderson, T. B., Kiehl, J. T., Large, W. G., McKenna, D. S., Santer, B. D., and Smith, R. D.: The Community Climate System Model version 3 (CCSM3), J. Climate, 19, 2122-2143, 2006.

de Vernal, A., Rosell-Mele, A., Kucera, M., Hillaire-Marcel, C., Eynaud, F., Weinelt, M., Dokken, T., and Kageyama, M.: Comparing proxies for the reconstruction of LGM sea-surface conditions in the northern North Atlantic, Quaternary Sci. Rev., 25, 28202834, doi:10.1016/j.quascirev.2006.06.006, 2006.

Dethloff, K., Dorn, W., Rinke, A., Fraedrich, K., Junge, M., Roeckner, E., Gayler, V., Cubasch, U., and Christensen, J. H.: The impact of Greenland's deglaciation on the Arctic circulation, Geophys. Res. Lett., 31, L19201, doi:10.1029/2004GL020714, 2004.

Eisenman, I., Bitz, C. M., and Tziperman, E.: Rain driven by receding ice sheets as a cause of past climate change, Paleoceanography, 24, PA4209, doi:10.1029/2009PA001778, 2009.

Felzer, B., Oglesby, R. J., Webb, T., and Hyman, D. E.: Sensitivity of a general circulation model to changes in northern hemisphere ice sheets, J. Geophys. Res.-Atmos., 101, 19077-19092, doi:10.1029/96JD01219, 1996.

Gent, P. R., Danabasoglu, G., Donner, L. J., Holland, M. M., Hunke, E. C., Jayne, S. R., Lawrence, D. M., Neale, R. B., Rasch, P. J., Vertenstein, M., Worley, P. H., Yang, Z. L., and Zhang, M. H.: The Community Climate System Model version 4, J. Climate, 24, 4973-4991, doi:10.1175/2011JCLI4083.1, 2011.

Hughes, P. D. and Woodward, J. C.: Timing of glaciation in the Mediterranean mountains during the last cold stage, J. Quater- 
nary Sci., 23, 575-588, doi:10.1002/jqs.1212, 2008.

Hunke, E. C. and Lipscomb, W. H.: CICE: The Los Alamos sea ice model user's manual, version 4, Los Alamos National Laboratory Tech. Rep. LA-CC-06-012, 76 pp., 2008.

Hurrell, J. W., Hack, J. J., Shea, D., Caron, J. M., and Rosinski, J.: A new sea surface temperature and sea ice boundary dataset for the Community Atmosphere Model, J. Climate, 21, 5145-5153, doi:10.1175/2008JCLI2292.1, 2008.

IPCC: Climate Change 2001: The Scientific Basis, Contribution of Working Group I to the Third Assessment Report of the Intergovernmental Panel on Climate Change, Cambridge University Press, Cambridge, United Kingdom and New York, NY, USA, 2001

Jahn, A., Claussen, M., Ganopolski, A., and Brovkin, V.: Quantifying the effect of vegetation dynamics on the climate of the Last Glacial Maximum, Clim. Past, 1, 1-7, doi:10.5194/cp-1-1-2005, 2005.

Jost, A., Lunt, D., Kageyama, M., Abe-Ouchi, A., Peyron, O., Valdes, P. J., and Ramstein, G.: High-resolution simulations of the last glacial maximum climate over Europe: a solution to discrepancies with continental palaeoclimatic reconstructions?, Clim. Dynam., 24, 577-590, doi:10.1007/s00382-005-0009-4, 2005.

Joussaume, S. and Taylor, K. E.: Status of the paleoclimate modeling intercomparison project (PMIP), in: Proceedings of the first international AMIP sciencific conference, WCRP-92, Monterey, USA, 425-430, 1995.

Junge, M. M., Blender, R., Fraedrich, K., Gayler, V., Luksch, U., and Lunkeit, F.: A world without Greenland: impacts on the Northern Hemisphere winter circulation in lowand high-resolution models, Clim. Dynam., 24, 297-307, doi:10.1007/s00382-004-0501-2, 2005.

Justino, F. and Peltier, W. R.: The glacial North Atlantic Oscillation, Geophys. Res. Lett., 32, L21803, doi:10.1029/2005GL023822, 2005.

Kageyama, M. and Valdes, P. J.: Impact of the North American ice-sheet orography on the Last Glacial Maximum eddies and snowfall, Geophys. Res. Lett., 27, 1515-1518, doi:10.1029/1999GL011274, 2000.

Kageyama, M., Valdes, P. J., Ramstein, G., Hewitt, C., and Wyputta, U.: Northern hemisphere storm tracks in present day and last glacial maximum climate simulations: A comparison of the European PMIP models, J. Climate, 12, 742-760, 1999.

Kageyama, M., Laine, A., Abe-Ouchi, A., Braconnot, P., Cortijo, E., Crucifix, M., de Vernal, A., Guiot, J., Hewitt, C. D., Kitoh, A., Kucera, M., Marti, O., Ohgaito, R., Otto-Bliesner, B., Peltier, W. R., Rosell-Mele, A., Vettoretti, G., Weber, S. L., and Yu, Y.: Last Glacial Maximum temperatures over the North Atlantic, Europe and western Siberia: a comparison between PMIP models, MARGO sea-surface temperatures and pollenbased reconstructions, Quaternary Sci. Rev., 25, 2082-2102, doi:10.1016/j.quascirev.2006.02.010, 2006.

Kim, S. J., Crowley, T. J., Erickson, D. J., Govindasamy, B., Duffy, P. B., and Lee, B. Y.: High-resolution climate simulation of the last glacial maximum, Clim. Dynam., 31, 1-16, doi:10.1007/s00382-007-0332-z, 2008.

Kutzbach, J. E. and Guetter, P. J.: The Influence of Changing Orbital Parameters and Surface Boundary-conditions On Climate Simulations For the Past 18000 Years, J. Atmos. Sci., 43, 1726-1759,
doi:10.1175/1520-0469(1986)043<1726:TIOCOP > 2.0.CO;2, 1986.

Laine, A., Kageyama, M., Salas-Melia, D., Voldoire, A., Riviere, G., Ramstein, G., Planton, S., Tyteca, S., and Peterschmitt, J. Y.: Northern hemisphere storm tracks during the last glacial maximum in the PMIP2 ocean-atmosphere coupled models: energetic study, seasonal cycle, precipitation, Clim. Dynam., 32, 593-614, doi:10.1007/s00382-008-0391-9, 2009.

Large, W. G. and Danabasoglu, G.: Attribution and impacts of upper-ocean biases in CCSM3, J. Climate, 19, 2325-2346, 2006.

Mahowald, N. M., Yoshioka, M., Collins, W. D., Conley, A. J., Fillmore, D. W., and Coleman, D. B.: Climate response and radiative forcing from mineral aerosols during the last glacial maximum, pre-industrial, current and doubled-carbon dioxide climates, Geophys. Res. Lett., 33, L20705, doi:10.1029/2006GL026126, 2006.

Manabe, S. and Broccoli, A. J.: The Influence of Continental Ice Sheets On the Climate of An Ice-age, J. Geophys. Res.-Atmos., 90, 2167-2190, doi:10.1029/JD090iD01p02167, 1985.

Mix, A. C., Bard, E., and Schneider, R.: Environmental processes of the ice age: land, oceans, glaciers (EPILOG), Quaternary Sci. Rev., 20, 627-657, doi:10.1016/S0277-3791(00)00145-1, 2001.

Neale, R. B., Richter, J. H., Conley, A. J., Park, S., Lauritzen, P. H., Gettelman, A., Williamson, D. L., Rasch, P. J., Vavrus, S. J., Taylor, M. A., Collins, W. D., Zhang, M., and Lin, S.: Description of the NCAR Community Atmosphere Model (CAM4), National Center for Atmospheric Research Tech. Rep. NCAR/TN+STR, 194 pp., 2010.

Oleson, K., Lawrence, D., Bonan, G., Flanner, M., Kluzek, E., Lawrence, P., Levis, S., Swenson, S., Thornton, P., Dai, A., Decker, M., Dickinson, R., Feddema, J., Heald, C., F. Hoffman, Lamarque, J.-F., Mahowald, N., Niu, G.-Y., Qian, T., Randerson, J., Running, S., Sakaguchi, K., Slater, A., Stockli, R., Wang, A., Yang, Z.-L., Zeng, X., and Zeng, X.: Technical Description of version 4.0 of the Community Land Model (CLM), NCAR Technical Note NCAR/TN-478+STR, National Center for Atmospheric Research, Boulder, CO, 257 pp., 2010.

Otto-Bliesner, B. L., Brady, E. C., Clauzet, G., Tomas, R., Levis, S., and Kothavala, Z.: Last Glacial Maximum and Holocene climate in CCSM3, J. Climate, 19, 2526-2544, doi:10.1175/JCLI3748.1, 2006a.

Otto-Bliesner, B. L., Tomas, R., Brady, E. C., Ammann, C., Kothavala, Z., and Clauzet, G.: Climate sensitivity of moderateand low-resolution versions of CCSM3 to preindustrial forcings, J. Climate, 19, 2567-2583, doi:10.1175/JCLI3754.1, $2006 \mathrm{~b}$.

Otto-Bliesner, B. L., Schneider, R., Brady, E. C., Kucera, M., AbeOuchi, A., Bard, E., Braconnot, P., Crucifix, M., Hewitt, C. D., Kageyama, M., Marti, O., Paul, A., Rosell-Mele, A., Waelbroeck, C., Weber, S. L., Weinelt, M., and Yu, Y.: A comparison of PMIP2 model simulations and the MARGO proxy reconstruction for tropical sea surface temperatures at last glacial maximum, Clim. Dynam., 32, 799-815, doi:10.1007/s00382-0080509-0, 2009.

Pausata, F. S. R., Li, C., Wettstein, J. J., Kageyama, M., and Nisancioglu, K. H.: The key role of topography in altering North Atlantic atmospheric circulation during the last glacial period, Clim. Past, 7, 1089-1101, doi:10.5194/cp-7-1089-2011, 2011.

Peltier, W. R.: Global glacial isostasy and the surface of the ice-age earth: The ice-5G (VM2) model and grace, Annu. Rev. Earth Pl. 
Sc., 32, 111-149, 2004.

Petersen, G. N., Kristjansoon, J. E., and Olafsson, H.: Numerical simulations of Greenland's impact on the Northern Hemisphere winter circulation, Tellus Ser. A, 56, 102-111, doi:10.1111/j.1600-0870.2004.00047.x, 2004.

Peyron, O., Guiot, J., Cheddadi, R., Tarasov, P., Reille, M., de Beaulieu, J. L., Bottema, S., and Andrieu, V.: Climatic reconstruction in Europe for 18,000 yr B.P. from pollen data, Quaternary Res., 49, 183-196, 1998.

Raible, C. C., Yoshimori, M., Stocker, T. F., and Casty, C.: Extreme midlatitude cyclones and their implications for precipitation and wind speed extremes in simulations of the Maunder Minimum versus present day conditions, Clim. Dynam., 28, 409423, doi:10.1007/s00382-006-0188-7, 2007.

Raible, C. C., Della-Marta, P. M., Schwierz, C., Wernli, H., and Blender, R.: Northern hemisphere extratropical cyclones: A comparison of detection and tracking methods and different reanalyses, Mon. Weather Rev., 136, 880-897, doi:10.1175/2007MWR2143.1, 2008.

Ramstein, G., Kageyama, M., Guiot, J., Wu, H., Hély, C., Krinner, G., and Brewer, S.: How cold was Europe at the Last Glacial Maximum? A synthesis of the progress achieved since the first PMIP model-data comparison, Clim. Past, 3, 331-339, doi:10.5194/cp-3-331-2007, 2007.

Schilt, A., Baumgartner, M., Schwander, J., Buiron, D., Capron, E., Chappellaz, J., Loulergue, L., Schupbach, S., Spahni, R., Fischer, H., and Stocker, T. F.: Atmospheric nitrous oxide during the last 140,000 years, Earth Planet. Sci. Lett., 300, 33-43, doi:10.1016/j.eps1.2010.09.027, 2010.

Shin, S. I., Liu, Z., Otto-Bliesner, B., Brady, E. C., Kutzbach, J. E., and Harrison, S. P.: A simulation of the last glacial maximum climate using the NCAR-CCSM, Clim. Dynam., 20, 127-151, doi:10.1007/s00382-002-0260-x, 2003.
Siddall, M., Rohling, E. J., Thompson, W. G., and Waelbroeck, C.: Marine Isotope Stage 3 Sea Level Fluctuations: Data Synthesis and New Outlook, Rev. Geophys., 46, RG4003, doi:10.1029/2007RG000226, 2008.

Strandberg, G., Brandefelt, J., Kjellstrom, E., and Smith, B.: Highresolution regional simulation of last glacial maximum climate in Europe, Tellus Ser. A., 63, 107-125, doi:10.1111/j.16000870.2010.00485.x, 2011.

Thackray, G. D., Owen, L. A., and Yi, C. L.: Timing and nature of late Quaternary mountain glaciation, J. Quaternary Sci., 23, 503-508, doi:10.1002/jqs.1225, 2008.

Toracinta, E. R., Oglesby, R. J., and Bromwich, D. H.: Atmospheric response to modified CLIMAP ocean boundary conditions during the Last Glacial Maximum, J. Climate, 17, 504-522, 2004.

Uppala, S. M., Kallberg, P. W., Simmons, A. J., Andrae, U., Bechtold, V. D., Fiorino, M., Gibson, J. K., Haseler, J., Hernandez, A., Kelly, G. A., Li, X., Onogi, K., Saarinen, S., Sokka, N., Allan, R. P., Andersson, E., Arpe, K., Balmaseda, M. A., Beljaars, A. C. M., Van De Berg, L., Bidlot, J., Bormann, N., Caires, S., Chevallier, F., Dethof, A., Dragosavac, M., Fisher, M., Fuentes, M., Hagemann, S., Holm, E., Hoskins, B. J., Isaksen, L., Janssen, P. A. E. M., Jenne, R., McNally, A. P., Mahfouf, J. F., Morcrette, J. J., Rayner, N. A., Saunders, R. W., Simon, P., Sterl, A., Trenberth, K. E., Untch, A., Vasiljevic, D., Viterbo, P., and Woollen, J.: The ERA-40 re-analysis, Q. J. Roy. Meteor. Soc., 131, 29613012, doi:10.1256/qj.04.176, 2005.

Wu, H. B., Guiot, J. L., Brewer, S., and Guo, Z. T.: Climatic changes in Eurasia and Africa at the last glacial maximum and mid-Holocene: reconstruction from pollen data using inverse vegetation modelling, Clim. Dynam., 29, 211-229, doi:10.1007/s00382-007-0231-3, 2007. 